\title{
DOMESTICATION OF FRESHWATER PUFFER FISH OR BUNTAL (Tetraodon palembangensis)
}

\author{
I Wayan Subamia*), Nina Meilisza*), Sudarto*, and Slamet Sugito*)
}

\begin{abstract}
The Research Institute for Freshwater Ornamental Fish Culture has been conducting domestication research since 2004 on adult freshwater puffer fish or buntal broodstock in which the fish were reared in aquaria and fed with small feed fish teri (anchovy) and earthworm (Lumbricus sp.). The domestication of freshwater puffer fish or buntal has resulted in successful environmental adaptation and reproductive ability of the fish and further rearing of its fry. The adaptive ability was indicated by its high survival rate, good growth and development, and the reproductive success in spawning, egg production, hatching as well as growing of the larvae to fry stages. The mature gonad stage of the fish was reached at an average body weight of $150 \mathrm{~g}$ with a reproductive period of 5 months. The spawning occurred naturally and the eggs were gradually released at interval periods of 14-18 days with egg production rates of 1,000-1,900 eggs per spawning. The highest egg fertilization rate was $96 \%$, with the highest egg hatching rate of $78.6 \%$. Hatching process took place on the $6^{\text {th }}$ to $13^{\text {th }}$ days after spawning process. The surviving larvae began feeding filtered natural foods Moina sp. on the $3^{\text {rd }}$ day up to the $6^{\text {th }}$ day, whereas unfiltered Moina $\mathrm{sp}$. was given from the $7^{\text {th }}$ to $14^{\text {th }}$ days. The fish were fed the live feed Culex sp. from the $15^{\text {th }}$ to $30^{\text {th }}$ days. In the following period the fish was fed earthworm and small feed fish teri (anchovy).
\end{abstract}

\section{KEYWORDS: domestication, adaptation, reproduction, freshwater} puffer fish or buntal (Tetraodon palembangensis)

\section{INTRODUCTION}

Domestication of fish species is an effort of utilization of fish for production as well as for conservation of the fish worldwide. Generally, fish domestication and culture have played an important role in increasing fish production in the last 18 years (Naylor et al., 2000). Domestication of the freshwater puffer fish or buntal (Tetraodon palembangensis) has been conducted in an attempt for the development of this species due to its economic value and uniqueness. In fisheries, the freshwater puffer fish or buntal (Tetraodon palembangensis) has a high economic value which is as competitive as with other freshwater fish species.
This species is of Asian origin such as Indonesia where it is found in the natural waters of Palembang in South Sumatera. The geographical distribution of freshwater puffer fish or buntal (Tetraodon palembangensis) in Asia comprises Indonesia, Laos, Thailand, and Malaysia. The environmental habitats of the fish are in demersal fresh waters of lakes and rivers in tropical regions.

To the local people where this fish is found, freshwater puffer fish or buntal (Tetraodon palembangensis) is a fish species used for local consumption. Related to that fact, it should be noted that great care is needed to safely discard the skins and internal organs before

\footnotetext{
"Research Institute for Freshwater Ornamental Fish Culture Depok, Indonesia
} 
processing of the fish because of their toxicity potential (Kottelat et al., 1993).

For a sustainable utilization of fish domestication, efforts are required to collect information regarding the basic biological and ecological data of the particular fish such as data on the aspects of reproduction, feed and feeding habit, behavior, spawning, and characteristics of their natural habitat (Haryono, 2008).

In the domestication study, available information on freshwater puffer fish or buntal (Tetraodon palembangensis) were collected and studied. Knowledge on behavior and living habit of the fish in its natural habitat will determine the success of domestication. Environmental conditions which are similar or made similar to those in the natural environment of the fish will also support the fish survival and its reproductive ability.

The freshwater puffer fish or buntal (Tetraodon palembangensis) is a unique freshwater fish that has a round body and an ability to float when facing external stress or disturbance. This species has a high survival rate. A small population size can have time intervals of recurrence of reproduction less than 15 months. The maximum size of the species ranges from $18.0-20.0 \mathrm{~cm}$ (7.1-7.9 inches) and it is not a dangerous species.

Optimal envionmental water qualities for the freshwater puffer fish or buntal (Tetraodon palembangensis) are as follows: water temperature of $24.0^{\circ} \mathrm{C}-27.0^{\circ} \mathrm{C}\left(75.2-80.6^{\circ} \mathrm{F}\right), \mathrm{pH} 6.9-$ 7.5, and water hardness (dGH) 7.0-18.0 N. Freshwater puffer fish or buntal (Tetraodon palembangensis) has friendly behavior to the environment and among themselves, but it tends to be aggressive toward other species. In aquaria, freshwater puffer fish or buntal (Tetraodon palembangensis) tend to swim in the lower part of water column. Due to their aggressive tendency, freshwater puffer fish or buntal (Tetraodon palembangensis) should be placed in spacious medium or, in case of small aquaria, be reared only one fish per aquarium (Anonim, 2008).

The position of the freshwater puffer fish or buntal in the taxonomical hierarchy of the fish is indicated in the Appendix. The objectives of domestication of the freshwater puffer fish or buntal (Tetraodon palembangensis) are to develop the adaptive ability of the fish to an environment outside its natural habitat and further to propagate the fish in fish culture envi- ronment.

\section{MATERIALS AND METHODS}

Rearing of the fish for domestication efforts comprises of preparation of rearing containers, water media, management of broodstock, feed and feeding management, reproduction process and rearing of the fry.

\section{Broodstock Cultural Management}

Individual body weight of Broodstock candidates of the freshwater puffer fish or buntal (Tetraodon palembangensis) used in this research were ranging from 150 to $200 \mathrm{~g}$. They were cultured in aquaria each has $60 \times 70 \times 50$ $\mathrm{cm}$ in size. Substrates provided for the fish in the form of flat stones on which the fish would lay eggs were placed in the aquaria. Cleaning and partial water echange were done daily by siphoning.

\section{Feed and Feeding}

The fish were fed earthworm (Lumbricus sp.) and small feed fish teri (anchovy). The fish were fed ad libitum daily in the morning.

\section{Reproduction and Spawning Behavior}

Reproduction of the fish was conducted by natural spawning. The natural spawning process was carried out for broodstocks with mature gonads. Morphological identification of broodstocks was observed visually. The mature gonad broodstocks were indicated by their round body shapes. The broodstock candidates were stocked in pairs of female and male into the aquaria. Flat stones were put in the aquaria as substrates on which the broodstocks would lay their eggs.

\section{Larval Rearing}

The eggs produced in the spawning process were then removed from the substrates and transferred into other prepared aquaria that each has $20 \times 40 \mathrm{~cm}$ in size and filled with water $10-15 \mathrm{~cm}$ deep. The water used for filling these latter aquaria had previously been prepared and mixed with salt at concentration of 2 ppt and treated with MB (Methylen Blue). The purpose of salt addition was to facilitate lysis of the eggshell, and the addition of MB was intended to protect the eggs and larvae from fungal infection. Continous observation of the eggs were conducted from 0 to 24 hours after spawning process and regular observations were continued up to the age of 7 days. 
The surviving larvae began feeding on the $3^{\text {rd }}$ day on filtered natural foods Moina sp. up to the $6^{\text {th }}$ day, whereas from the $7^{\text {th }}$ to $14^{\text {th }}$ days unfiltered Moina sp. was given.

\section{Fry Rearing}

The fries obtained from larval rearing were reared for 15 days in aquaria of $60 \times 70 \times 50 \mathrm{~cm}$ in size at a stocking density of 10 individual fries per liter. On the $15^{\text {th }}$ through $30^{\text {th }}$ day, the fries were fed the live feed Culex sp , afterward the fries was fed with earthworm and small feed fish teri (anchovy) which had been cut into fine pieces according to size to the mouth opening of the fry.

\section{RESULTS AND DISCUSSIONS}

The domestication of the freshwater puffer fish or buntal (Tetraodon palembangensis) was successful in developing fish ability to adapt to the new environment and be able to reproduce. The adaptive ability of the fish was indicated by its fine adjustment to the new environment in the aquarium. Rearing the fish in new aquarium environment will change its behavior.

Natural spawning process began when the female broodstock laid eggs on the substrate. Then the male broodstock drove the female away from the substrate and fertilized the eggs. After fertilizing the eggs, the male stayed on the substrate to guard the fertilized eggs whereas the female stayed away from the substrate. Continous observations were made for as long as the male remained on the substrate because the external stresses and disturbances could cause the fertilized eggs eaten by the male. To avoid this possible undesired behavior of the male, the eggs were transferred into other aquaria.

Spawning took place successfully in two pairs of broodstocks at two different aquaria. Spawning of the freshwater puffer fish or buntal (Tetraodon palembangensis) occurred partially. In one period, a pair of broodstocks could repeat reproductive processes four to five times at time intervals ranging from 14 to 18 days. The total of produced eggs (fecundity) were more than 1,000-1,900 eggs. The highest fertilization rate was $96 \%$ and the highest hatching rate was $78.6 \%$. The egg shape of the fish was flat on the lower side, convex on the upper side, with a clear and transparent colour. An oil film was also seen on the eggs, which were generally the eggs laid on the substrate.

The eggs hatched from the $6^{\text {th }}$ to $13^{\text {th }}$ day in two ways. Firstly, the eggshell underwent lysis or peeled away when the larval tail came out first of the eggshell. Secondly, the eggshell was torn or broken apart by the movement of the larval head out of the eggshell. After hatching, some of the larvae moved to the water surface and the rest stayed on the bottom of aquarium.

The domestication process of the freshwater puffer fish or buntal (Tetraodon palembangensis) was successfully obtained from two pairs of broodstock with mature gonad. From two pairs of broodstock, three periods or seasons of partial spawning occurred. A total of 11 partial spawning processes occurred, seven of which were followed by successful egg hatching.

Results of observations on the development of egg and embryo are as follows:

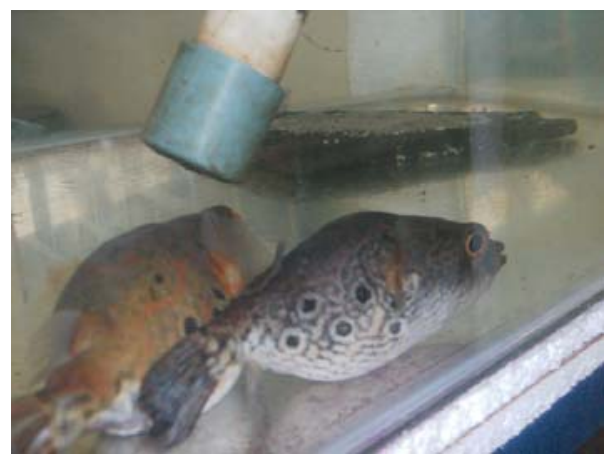

Figure 1. The broodstock of freshwater Puffer fish or buntal (Tetraodon palembangensis)

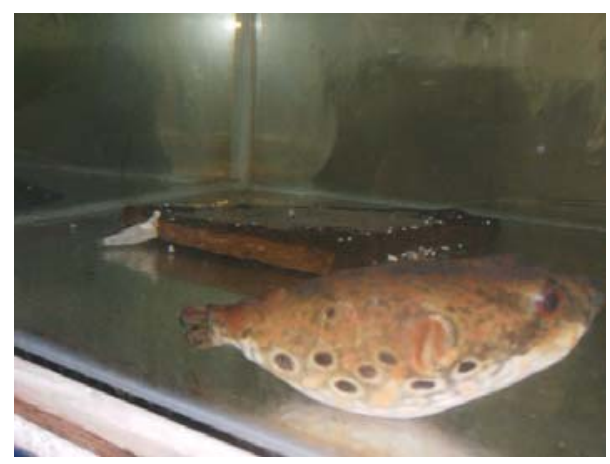

Figure 2. The female laid eggs 


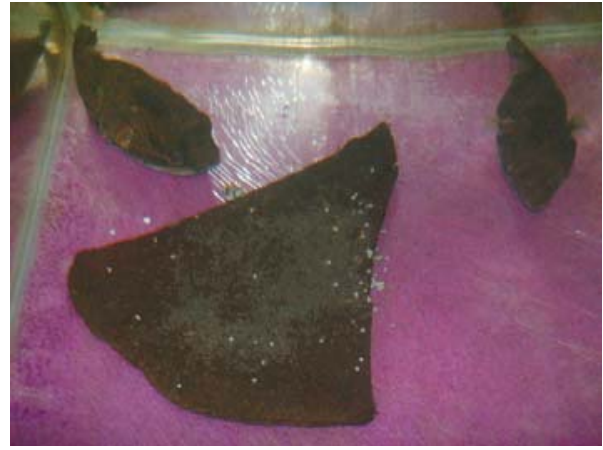

Figure 3. The male drove the female out of the substrate

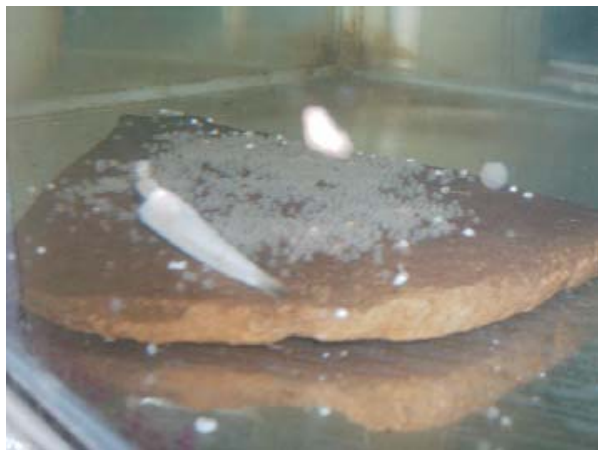

Figure 5. The eggs were transferred into another aquarium

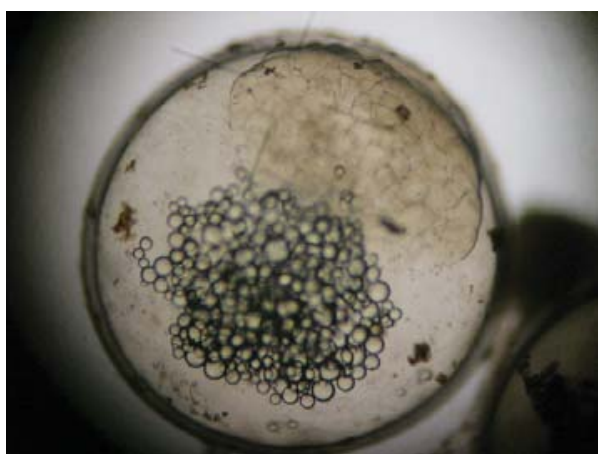

Figure 7. The development of eggs

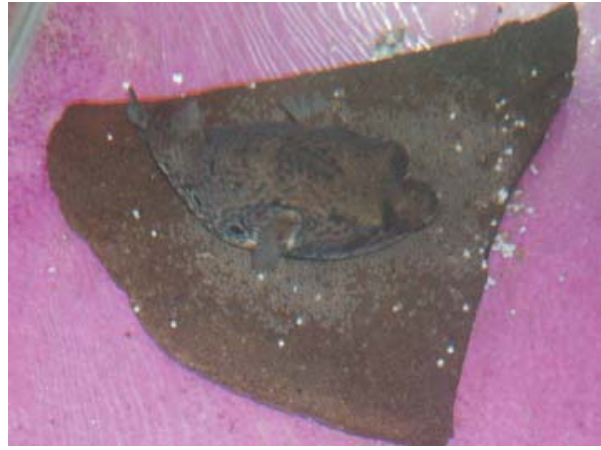

Figure 4. The male fertilized the eggs

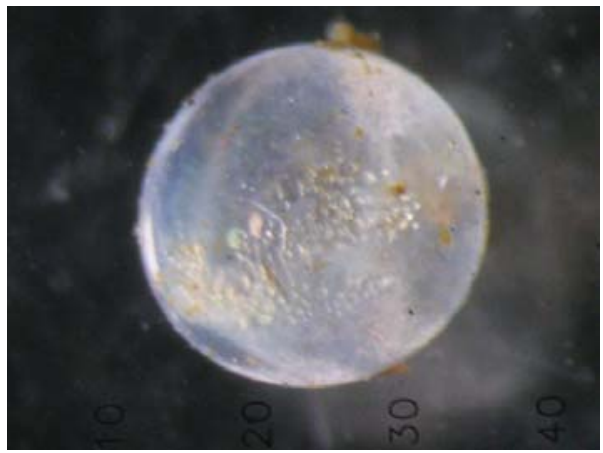

Figure 6. The shape of the freshwater Puffer fish or buntal egg as was viewed from the upper side

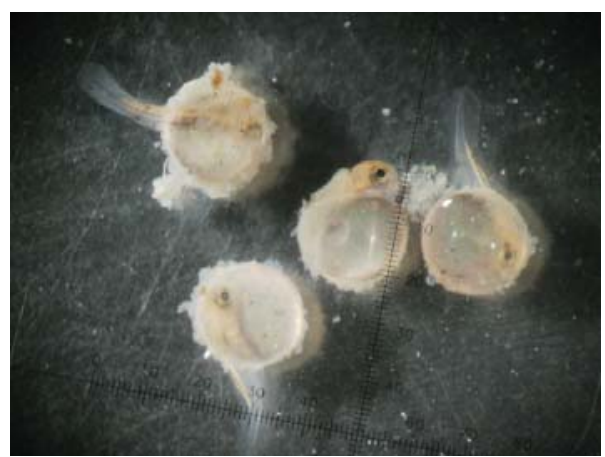

Figure 8 . The hatched eggs 


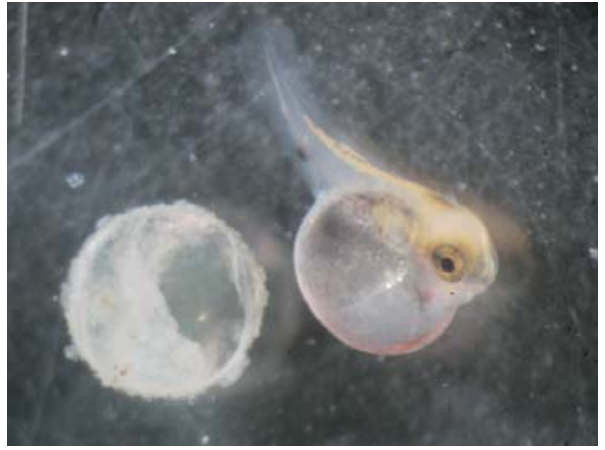

Figure 9. The hatched eggs

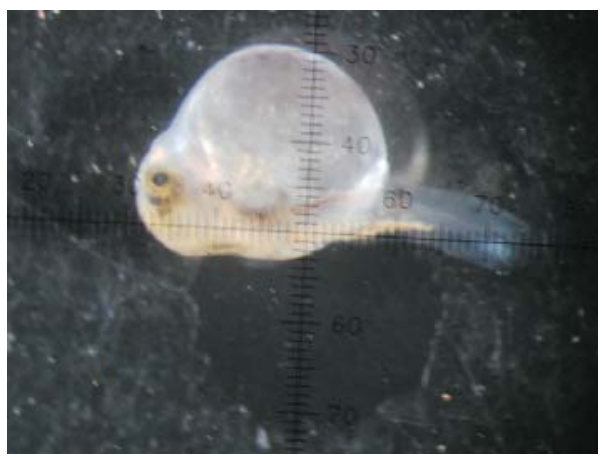

Figure 11. Larva development

\section{CONCLUSIONS}

Domestication of the freshwater puffer fish or buntal (Tetraodon palembangensis) carried out by the Research Institute of Freshwater Ornamental Fish Culture was successful in the aspects of developing the ability of the fish to adapt to a new environment outside their natural habitat, reproductive ability of two pairs of broodstock in the form of natural spawning ability, and rearing the fry.

\section{REFERENCES}

Anonim. 2004. Catalog of Fishes, 13-May-2004, website (version 10-May-04). http:// www.calacademy.org/research/ichthyology/catalog. 20/09/2008, pk. 10.55 WIB.

Anonim. 2008. Fishbase. http://www.fishbase. org. 05/08/2008, pk. 12.00 WIB.

Haryono. 2008. Proses Domestikasi Ikan Tambra (Tor spp.) Untuk Pemanfaatan Berkelanjutan.http://www.biotek.lipi.go.id/

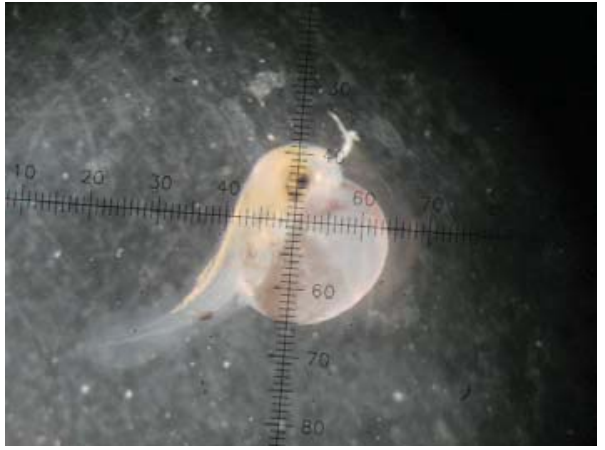

Figure 10. Larvae

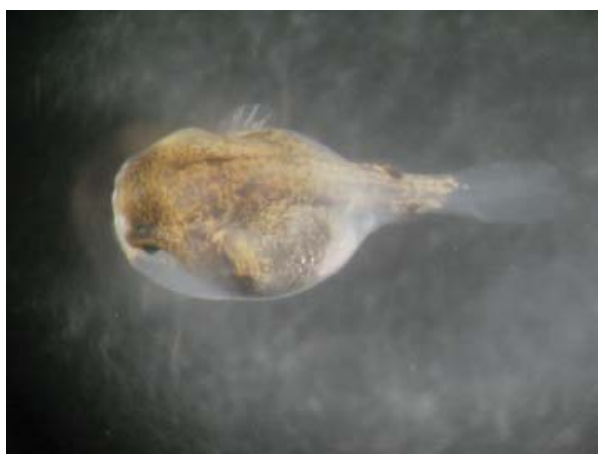

Figure 12. The fry of freshwater Puffer fish or buntal (Tetraodon palembangensis)

$\mathrm{iph} / \mathrm{programmes} / \mathrm{biology} / \mathrm{biology}$ haryono.html. 5/8/2008, pk. 11.20 WIB.

Kottelat, M., A.J. Whitten, S.N. Kartikasari, and S. Wirjoatmodjo. 1993. Freshwater fishes of Western Indonesia and Sulawesi. Periplus Editions, Hong Kong. 221 pp.

Naylor, R.L., R.J. Goldburg, J.H. Primavera, N. Kautsky, M.C.M. Beveridge, J. Clay, C. Folke, J. Lubchenco, H. Mooney, and M. Troell. 2000. Effect of aquaculture on world fish supplies, Nature. 405: 1,017-1,024. 
Appendix 1. Taxonomical hierarchy of the freshwater puffer fish or Buntal (Tetraodon palembangensis) (Anonim, 2004)

Kingdom: Animalia

Phylum: Chordata

Subphylum: Vertebrata

Superclass: Osteichthyes

Class: Actinopterygii

Subclass: Neopterygii

Infraclass: Teleostei

Superorder: Acanthopterygii

Order: Tetraodontiformes

Suborder: Tetraodontoidei

Family: Tetraodontidae

Subfamily: Tetraodontinae

Genus: Tetraodon Linnaeus, 1758

Species: Tetraodon palembangensis Bleeker, 1852 